Journal : JMMR (Jurnal Medicoeticolegal dan Manajemen Rumah Sakit), 10 (1): 22-34, April 2021

Website : http://journal.umy.ac.id/index.php/mrs

DOI $\quad$ : https://doi.org/10.18196/jmmr.v10i1.10141

\title{
Service Quality and Customer Satisfaction on WOM a Private Hospital in Indonesia
}

\author{
Tantri Yanuar Rahmat Syah ${ }^{1 *}$, Cahyo Kusumo Wijoyo ${ }^{2}$ \\ $1^{*}$ Correspondence Author: tantri.yanuar@esaunggul.ac.id \\ 1,2, Master of Management Study Program, Esa Unggul University, Arjuna Utara Street No. 09, KebonJeruk, Jakarta, Indonesia

\section{N D E X I N G \\ Keywords: \\ Customer Satisfaction; \\ Service Quality; \\ Word of Mouth}

\begin{abstract}
A B S T R AC T
This research examines the effect of service quality and customer satisfaction on word of mouth. We carried out a survey of our sample, which consisted of 303 respondents. This study provides empirical evidence that service quality has a significant positive effect on customer satisfaction, service quality also has a significant positive effect on word of mouth and customer satisfaction has a significant positive effect on word of mouth.
\end{abstract}

\section{Kata Kunci:}

Kepuasan pelanggan;

Kualitas Pelayanan;

Word of Mouth.
Penelitian ini menguji pengaruh kualitas layanan dan kepuasan pelanggan terhadap word of mouth. Kami melakukan survei terhadap sampel kami, yang terdiri dari 303 responden. Penelitian ini memberikan bukti empiris bahwa kualitas layanan berpengaruh positif signifikan terhadap kepuasan pelanggan, kualitas layanan juga berpengaruh positif signifikan terhadap word of mouth dan kepuasan pelanggan berpengaruh positif signifikan terhadap word of mouth.
(C) 2021 JMMR. All rights reserved

\section{INTRODUCTION}

The rapid development of the medical environment at the local and global level has encouraged hospitals to implement various changes. The medical industry in general is progressive, more productive, and developing quickly, along with the rapid improvements in medical science and technology (Kulsum \& Syah, 2017). Given the changes that tend to accelerate with the emergence of various new government policies, technology, the economy, consumer behavior, market growth, competitor strategies, and other factors that result in a more competitive situation, then the right strategy is needed to manage the healthcare services offered by hospitals. Hospitals are in the healthcare service business, based on the principle of trust from their customers. Thus, service quality, customer satisfaction, and word of mouth determine the success of a hospital's business.

Health care is a dynamic and rapidly growing public service market sector that faces increasing competition and significant changes (Dagger, 2007). Customer satisfaction is considered to be a feeling of happiness or disappointment for the customers, which comes from their comparison between the performance or results of a service or product, and their expectations of it, where the context of customer satisfaction is an estimate, or customer confidence in what they receive. In other words, customer satisfaction is the quality of service as determined by the opinions of the consumers (Kotler \& Keller, 2009).

Product or service quality is one of the keys to success in competition. The quality of products and services provided by a company will affect the company's reputation in the eyes of consumers and will ultimately affect the consumers' loyalty to the company (Syah, 2013). In hospitals, improved service quality is related to patient satisfaction, so if there is an increase in the services received by patients, and the patients' satisfaction increases, this will have an 
impact on the patients' loyalty (Nurlitasari \& Syah, 2016). Service quality is a key factor to get customer satisfaction that will increase customer loyalty (Ajami et al., 2018).

Customer loyalty includes the attitude component and the customer behavior component, which is related to a customer's attitude, which is reflected in the intention to return to buy the product, the willingness to recommend the company to others (word of mouth), not to move to other products and be willing to pay a price premium (Anselmsson et al, 2014). Research by Yu et al. (2017) examined site-level (website quality and interactivity) and consumer-level (satisfaction, attitude, stickiness) values, but the study did not examine any hedonic value variables as one of the antecedents that affect word of mouth.

Word of mouth refers to informal communications between individuals about ownership, use, and certain characteristics of goods and services, sellers, services, and social issues (Yu et al., 2017). Generating positive word of mouth is an important marketing strategy for online businesses because it can significantly influence consumers' purchasing decisions (Smith et al., 2007). Dissatisfaction often results in customers going out or spreading negative feedback through word of mouth (Lai \& Chou, 2015). However, if the right service recovery strategy is applied, then positive confirmation from customers can be achieved, so as to turn dissatisfied customers into satisfied and loyal customers who spread positive messages by word of mouth (Lankton \& McKnight, 2012).

The quality of service has a very significant influence on word of mouth (Mukerjee, 2018). Trusov (2000) said that communicating by word of mouth is more influential than communication through other promotional methods. Customers who are very satisfied with certain products or services will have the enthusiasm to introduce those products or services through word of mouth to anyone they know (Griffin, 2003). Customers who get products or services that meet or exceed expectations, tend to give a positive response to the company, one of them, giving word of mouth to his colleagues. Word of mouth is an effective way to build a positive image for a hospital, besides the fact that word of mouth can also increase the number of purchases and sales (Handini \& Ruswanti, 2016). It has been established that high service quality provides benefits, which include customer satisfaction and positive word of mouth communications (Ilyas et al., 2013).

Based on research conducted by Susanto (2018), Ajami et al. (2018), Zaim et al. (2013) and Bakti (2013), service quality is related to customer satisfaction, which will lead to customer loyalty. Meanwhile, customer loyalty has three dimensions, namely: word of mouth, switching behavior, and product repurchase. However, in today's rapidly developing digital era, one thing that is very important for maintaining customer loyalty is word of mouth, which will be the focus of this research, because, in terms of services, hospitals provide services in a people-to-people manner. So through positive word of mouth a hospital's business will grow faster or, if the word of mouth is negative it will worsen.

From the background description above, the objectives of the research are: (1) To find out the relationship between service quality and patients' satisfaction in a hospital in Indonesia. (2) To find out the relationship between service quality and word of mouth in a hospital in Indonesia. (3) To find out the relationship between patient satisfaction and word of mouth in a hospital in Indonesia. 


\section{RESEARCH METHOD}

This research used a quantitative approach with the primary data being collected using the questionnaire survey method. This research started by developing its hypotheses which involved finding the right procedures for using a specific data source. We conducted our survey in a private hospital in Indonesia. The research started in December 2019 and was conducted for 30 days from 09.00 to 16.00 every day by directly meeting the respondents and inviting them to fill out the questionnaire. The population in this study consisted of public (private) patients who attended an outpatient examination (polyclinic and emergency room) at the hospital. The sampling technique used in this study was purposive sampling. The sample in this study is that some of the customers in this case are outpatients (polyclinic and emergency room). The sample taken in this study has the following criteria: private patients, or old patients who have had an outpatient's examination (polyclinic and emergency room), or existing customers who have had at least 2 examinations as outpatients at the hospital.

The variables involved in this study were the service quality as an exogenous variable. The instrument used to measure service quality was based on the instrument developed by Parasuraman (1988). The quality of service included 22 question items with indicators including: tangibles, reliability, responsiveness, assurance and empathy. To measure each of the research instruments, a Likert scale was used, with five alternative answers: strongly disagree (SD), disagree (D), neither agree or disagree (BAD), agree (A) and strongly agree (SA) (Sugiyono, 2011).

Before being used in the actual research, the research questionnaire's instruments were tested first. The trial of these instruments was conducted on 33 respondents outside the population that were sampled in the actual research. From the results of the validity and reliability test of the 28 questions in the questionnaire, 26 passed the tests with a KaiserMeyer-Olkin (KMO) value $>0.500$ and a Cronbach's alpha value of $>0.600$ (Appendix 9). This research's population was not limited; therefore, the number of samples could be calculated based on the total number of questionnaires that passed the validity and reliability test $\times 5$, ie $26 \times 5=130$ respondents. Hair et al. (2013) suggested that the minimum sample size is 5 to 10 observations for each estimated parameter, so the sample used in this study amounted to 26 items $\mathrm{x}$ 5. So, the minimum number of samples needed was 130 respondents. In this case the researcher used a sample of 303 respondents. The testing phase conducted in this study was assisted by structural equation modeling (SEM) with the linear structural relations (LISREL) program (Ghozali, 2014).

\section{RESULT AND DISCUSSION}

The profiles of the 303 respondent patients treated at the hospital showed that the majority of patients were women (53.1\%), aged between 26 to 35 years old (30.4\%), 64.4\% held a bachelor's degree (S1), with $47.9 \%$ of them employed as private employees, with a monthly income > Rp. 3,850,000. This showed that the hospital's patients were of a productive age, with a high education, had jobs as private employees and who already had an awareness of healthy lifestyles. 
Table 1. Profile of Respondents.

\begin{tabular}{llcc}
\hline \multicolumn{1}{c}{ Characteristics } & \multicolumn{1}{c}{ Profil } & Number of Respondents & $\%$ \\
\hline Sex & Male & 142 & $46.9 \%$ \\
\hline & Female & 161 & $53.1 \%$ \\
\hline Age & TOTAL & 303 & $100.0 \%$ \\
\hline & $17-25$ years old & 42 & $13.9 \%$ \\
\hline & $26-35$ years old & 92 & $30.4 \%$ \\
\hline & $36-45$ years old & 84 & $27.7 \%$ \\
\hline & $46-55$ years old & 49 & $16.1 \%$ \\
\hline & $>56$ years old & 36 & $11.9 \%$ \\
\hline Last education & TOTAL & 303 & $100.0 \%$ \\
\hline & Junior High School & 4 & $1.3 \%$ \\
\hline Senior High School & 42 & $13.8 \%$ \\
\hline & D3 & 22 & $7.3 \%$ \\
\hline & S1 & 195 & $64.4 \%$ \\
\hline S2 & 36 & $11.9 \%$ \\
\hline S3 & 4 & $1.3 \%$ \\
\hline Profession & TOTAL & 303 & $6.8 \%$ \\
\hline Student / College & 21 & $8.9 \%$ \\
\hline & PNS / TNI / POLRI & 27 & $47.9 \%$ \\
\hline Private employees & 145 & $11.6 \%$ \\
\hline & BUMN & 35 & $24.8 \%$ \\
\hline Others & 75 & $100.0 \%$ \\
\hline Monthly income & TOTAL & 303 & $6.9 \%$ \\
\hline Rp < 3,850,000- & 21 & $93.1 \%$ \\
\hline Rp $>3,850,000-$ & 282 & $100.0 \%$ \\
\hline & TOTAL & 303 & \\
\hline
\end{tabular}

The results of the structural equation's output from LISREL version 8.8., showed that service quality (SQ) had a greater positive effect on customer satisfaction (CS) that was equal to 0.79 , with a value of $R$ Square $\left(R^{2}\right)=0.62$. Service quality (SQ) had a greater positive effect on word of mouth (WOM), which was equal to 0.46 and customer satisfaction (CS) had a smaller positive effect on word of mouth (WOM), which amounted to 0.40 , with a value of $R$ Square $\left(R^{2}\right)=0.67$.

The results of the output reduced form equation from LISREL version 8.8., showed that service quality (SQ) had a greater positive effect on customer satisfaction (CS) that was equal to 0.79 , with a value of $R$ Square $\left(R^{2}\right)=0.62$. Service quality $(S Q)$ had a smaller positive effect on word of mouth (WOM) which was equal to 0.78 , with a value of $\mathrm{R}$ Square $\left(\mathrm{R}^{2}\right)=0.61$.

We tested the suitability of this model using structural equation modeling (SEM) with the LISREL program version 8.8. The following goodness of fit index was generated after testing: 
Table 2. The Result of Goodness of Fit Index Structural Equation Modeling (SEM)

LISREL Version 8.8

\begin{tabular}{|c|c|c|c|}
\hline Group & Indicator & Value & Information \\
\hline \multirow[t]{6}{*}{1} & Degrees of Freedom & 36 & \multirow{6}{*}{ Good Fit } \\
\hline & Chi-Square & 54.55 & \\
\hline & Chi Square / Degree of Freedom & $54.55 / 36=1.51$ & \\
\hline & Probability $(P)$ & 0.024 & \\
\hline & Estimated Non-centrality Parameter (NCP) & 18.55 & \\
\hline & Confidence Interval for NCP & $2.54: 42.52$ & \\
\hline \multirow[t]{3}{*}{2} & Root Mean Square Error of Approximation (RMSEA) & 0.041 & \multirow[t]{3}{*}{ Good Fit } \\
\hline & Confidence Interval for RMSEA & $0.015: 0.063$ & \\
\hline & P-Value for Test of Close Fit $($ RMSEA < 0.05$)$ & 0.73 & \\
\hline \multirow[t]{4}{*}{3} & Expected Cross-Validation Index (ECVI) Model & 0.38 & \multirow[t]{4}{*}{ Good Fit } \\
\hline & ECVI for Saturated Model & 0.44 & \\
\hline & ECVI for Independence Model & 6.80 & \\
\hline & Confidence Interval for ECVI & $0.33: 0.46$ & \\
\hline \multirow[t]{6}{*}{4} & Model AIC & 114.55 & \multirow[t]{6}{*}{ Good Fit } \\
\hline & Saturated AIC & 132.00 & \\
\hline & Independence AIC & $2,052.75$ & \\
\hline & Model CAIC & 255.97 & \\
\hline & Saturated CAIC & 443.11 & \\
\hline & Independence CAIC & $2,104.60$ & \\
\hline \multirow[t]{6}{*}{5} & Normed Fit Index (NFI) & 0.97 & \multirow[t]{6}{*}{ Good Fit } \\
\hline & Non-Normed Fit Index (NNFI) & 0.99 & \\
\hline & Parsimony Normed Fit Index (PNFI) & 0.64 & \\
\hline & Comparative Fit Index (CFI) & 0.99 & \\
\hline & Incremental Fit Index (IFI) & 0.99 & \\
\hline & Relative Fit Index (RFI) & 0.96 & \\
\hline 6 & Critical N (CN) & 334.31 & Good Fit \\
\hline \multirow[t]{3}{*}{7} & Goodness of Fit Index (GFI) & 0.97 & \multirow[t]{3}{*}{ Good Fit } \\
\hline & Adjusted Goodness of Fit Index (AGFI) & 0.94 & \\
\hline & Parsimony Goodness of Fit Index (PGFI) & 0.53 & \\
\hline
\end{tabular}

Source: Primary Data Processed January 2020.

From the results of the goodness of fit index's measurement above (Table 2), it can be concluded that all the parameters met the expected conditions. Regarding the item indicators, namely: chi square, RMSEA, ECVI, AIC \& CAIC, fit index, critical N and GFI \& AGFI, they are all a good fit. From the summary of the results from LISREL version 8.8., this analysis was chosen to determine the gradual influence on service quality, customer satisfaction and word of mouth, and, as explained in the literature review above, three hypotheses were formulated by this study. To find out whether the hypotheses were supported by the data or not, the t-value was compared with the t-table of 1.96 (Ghozali, 2014). If the t-value $>1.96$, it could be concluded that the research's hypotheses were supported by the data (and proven significantly).

An image of the test model of the research model, and the test of the hypotheses using the LISREL version 8.8., is shown below. The hypotheses test results and the tests of the 
causality relationship of each research variable are also presented in the following figure 2 and table 2 .

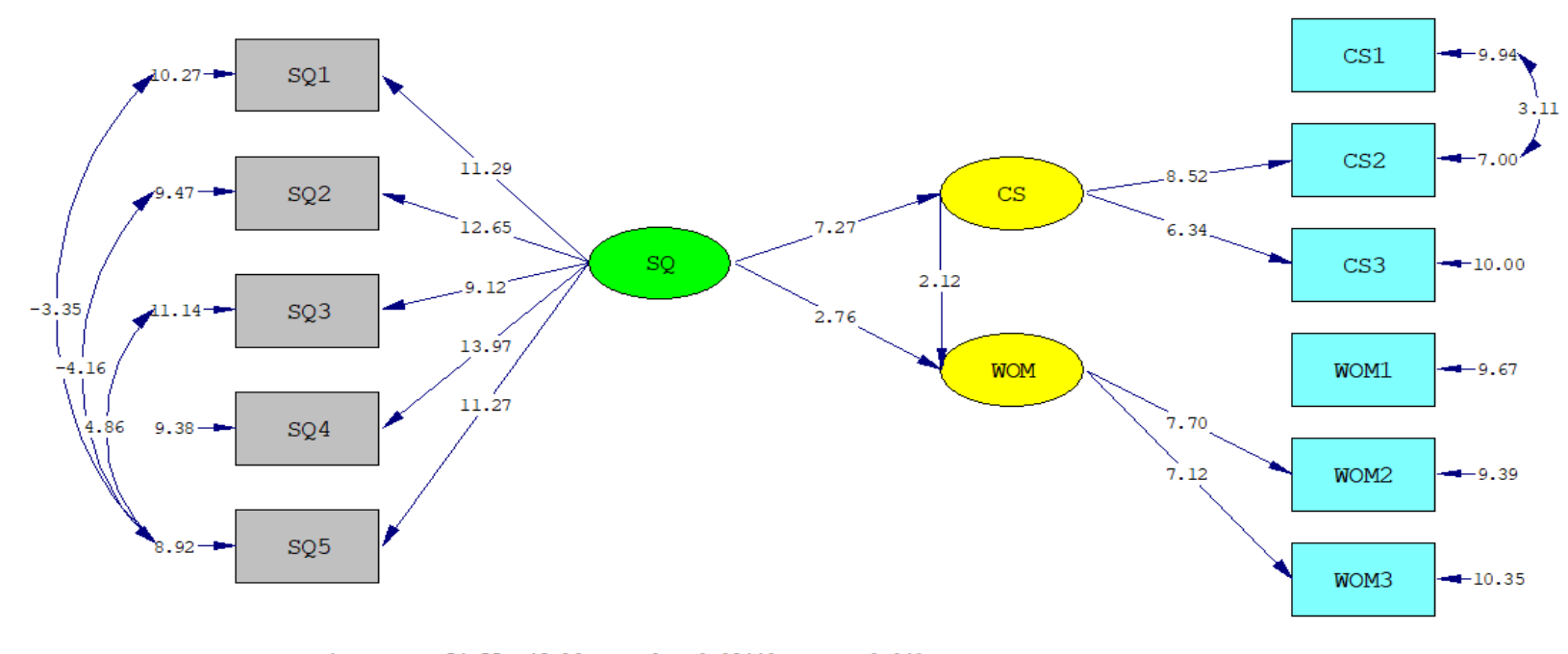

Figure 2. Results of the Research Model (LISREL Path Diagram Version 8.8.)

Table 2. Estimation Results with LISREL Model Version 8.8.

\begin{tabular}{lcccc}
\multicolumn{1}{c}{ Variab;eRealtionship } & Path Coefficient & T-Value & T-Table & Information \\
\hline $\begin{array}{l}\text { Service Quality } \rightarrow \text { Customer } \\
\text { Satisfaction }\end{array}$ & 0.79 & 7.27 & 1.96 & H1 received \\
\hline $\begin{array}{l}\text { Service Quality } \rightarrow \text { Word of } \\
\text { Mouth }\end{array}$ & 0.46 & 2.76 & 1.96 & H2 received \\
\hline $\begin{array}{l}\text { Customer Satisfaction } \rightarrow \\
\text { Word of Mouth }\end{array}$ & 0.40 & 2.12 & 1.96 & H3 received \\
\hline
\end{tabular}

Source: Primary Data Processed January 2020.

The results show the direct effect of service quality on customer satisfaction. The path coefficient was 0.79 , the t-value was above the t-table's value $(7.27>1.96)$ so that the relationship between these two variables is statistically significant. This result provides empirical evidence about the positive effect of service quality on customer satisfaction. This indicates that the better the quality of the service provided to customers is, the higher the customers' satisfaction will be. Therefore, the first hypothesis is supported.

The direct effect of service quality on word of mouth was found. The path coefficient was 0.46 and the $t$-value was above the t-table's value $(2.76>1.96)$. This result indicates that service quality has a significant positive effect on word of mouth. The better the quality of the service provided to customers is, the more likely that word of mouth will increase. Therefore, the second hypothesis is supported.

Finally, we found the direct effect of customer satisfaction on word of mouth. The path coefficient was 0.40 and the t-value was above the t-table's value $(2.12>1.96)$. This result provides empirical evidence that customer satisfaction has a significant positive effect on word of mouth. The more satisfaction that a customer feels, the more likely it is that word of mouth will increase. This result supports our third hypothesis. 


\section{Discussions}

\section{Quality of Service Improves Customer Satisfaction}

This research successfully demonstrated that service quality has a positive effect on customer satisfaction. This means that better quality service, will have a positive impact on customer satisfaction, so there will be fewer complaints from customers about the quality of the service. The findings of this study support the previous research conducted by Thurau (2004) which stated that the quality of customer service affects their relationships both directly and indirectly and causes increased customer satisfaction. According to Mittal \& Gera (2013), in terms of service quality, the importance of service quality's dimensions and customer behavior can be drawn a relationship, that customers' perceptions of service quality affect their overall satisfaction and the customers' perceptions of values that provide a positive relationship with the intensity of behavior and retention of customers, so the concept of customer satisfaction can be seen within a certain scope, such as in a store, where customers' satisfaction will be closely related to the intent to repurchase. Whereas according to Kartawidjaja \& Syah (2016) feedback and information are important elements for building an effective service delivery system, including the level of customer satisfaction and improvement in the service's quality.

Haghighi et al. (2012) concluded that a positive service quality can increase satisfaction; this is due to the quality of service that is described by the dimensions of responsiveness and physical evidence so it becomes a real thing that is prioritized by customers. Rampl et al. (2012) found that service quality had a positive and significant effect on customer satisfaction; this is due to improvements to people's ability to serve customers.

Research conducted by Hisam et al. (2016) concluded that there was a relationship between service quality and customer satisfaction, but that study only examined the relationship between variables and did not seek for a relationship from the existing dimensions. In a study of the service quality of electronic services, it was found that the quality of electronic services was strongly correlated with customer satisfaction (Ajami et al., 2018). Research conducted by Kulsum \& Syah (2017) concluded that maximum service quality will increase the patients' satisfaction. Service quality has a significant positive effect on patients' satisfaction (Kartawidjaja \& Syah, 2016).

\section{Quality of Service Improves Worf of Mouth}

This study shows that service quality has a positive effect on word of mouth. This means that the better the quality of the services provided, positive word of mouth will recommend the services offered, thus impacting on the number of customer visits. Wong \& Sohal (2003) explained that plenary service quality is something that needs to be pursued to make a positive and significant influence on customer loyalty; this condition is because customers will prefer to stay in a restaurant that is able to serve their every need. Hamenda (2018) provided an explanation that service quality is able to influence loyalty, due to the staffs' empathy for the customer. Customer loyalty is related to all the things that can attract customers, and make them buy a product, buy it repeatedly (often), buy it in greater quantities and bring in even more customers with a word of mouth promotion system (Fornell, 1992). Li (2013) suggested that service quality is positively related to word of mouth. Word of mouth is considered to be a network of customer relationships that can ensure that 
businesses (betul, intinya untuk memperkuat bahwa dipenelitian lainpun ada penelitian yang hasilnya sama dengan penelitian ini) gain a competitive advantage, which is essential for their success (Hsu, 2018).

\section{Customer Satisfaction Increases Word of Mouth}

This research successfully demonstrated that customer satisfaction has a positive effect on word of mouth, meaning that the greater satisfaction felt by the customers will cause them to pass on their satisfaction by word of mouth and recommend the business to others. Ngo (2015) provided an explanation that customer satisfaction plays a major role in shaping customer loyalty, which is caused by the comfort that is generated. This finding indicates that customer satisfaction is one of the items that are able to encourage customers to be loyal to a company. Gures et al. (2014) explained that customer satisfaction is able to have an impact on customer confidence, so they keep using the product. Netemeyer et al. (2010) provided the view that customer satisfaction encourages customers to continue to buy and use the products; they will then recommend the products by word of mouth to others.

Research conducted by Yu et al. (2017) successfully demonstrated that customer satisfaction has a positive effect on word of mouth, meaning that the greater satisfaction felt by the customers will cause them to make positive recommendations by word of mouth to other people. Customer satisfaction is important for service providers, because happy customers spread a sense of satisfaction to potential customers, thus increasing the company's reputation. So if customers are satisfied, they will make positive word of mouth recommendations to their colleagues and family (Burnham \& Leary, 2018). This serves to link the processes that lead to purchases and consumption, with post-purchase phenomena such as switching behavior, repeated purchases and word of mouth (Churchill, 2016). Customers who get products or services that meet or exceed their expectations, tend to give a positive response to the company. One of them is by giving positive word of mouth to other shoppers. Word of mouth is an effective way to build a positive image for a hospital, besides the fact that it can also increase the number of purchases and sales (Handini \& Ruswanti, 2016).

The exponential growth in the use of online social media, which makes word of mouth easier to spread to many people, has made word of mouth very prominent (Gopinath et al., 2014). In addition, research shows that word of mouth has a significant impact on the formation of a consumer's attitude, positive word of mouth can reduce the risk associated with purchasing products or services (Srinivasan et al, 2002). As an important but difficult to manage marketing power, word of mouth is believed to be able to complement and extend the effects of advertising (Hogan \& Lemon, 2004). For example, initial marketing activities (advertising, promotion) trigger an initial purchase reaction, then purchasing experiences trigger the spread of word of mouth, as people share their experiences with others (Chevalier et al., 2003). The company develops loyal customers, so they can be very valuable assets for the company. The customers not only continue to use the company's products or services, but they themselves will also recommend the company by word of mouth to others, according to their experiences (Yarimoglu, 2014).

According to Handini \& Ruswanti (2016) word of mouth plays an important role in marketing Rumah Sehat Wanita Hauraa, so that patient's satisfaction has a significant effect 
on word of mouth. According to the research of Brown et al. (2005) customer satisfaction is highly positively correlated with word of mouth. Therefore, it is very clear that customer satisfaction is a key variable that influences word of mouth intentions. Customer satisfaction alone cannot be responsible for driving future purchasing power or spreading positive recommendations by word of mouth. In addition, customer loyalty will also lead to positive word of mouth intentions. The presence of loyalty will definitely have a different impact on the customer's word of mouth intentions (Burnham \& Leary, 2018).

\section{CONCLUSION}

The results of this study conclude that service quality has a significant positive effect on customer satisfaction, the better the quality of the service offered, the greater will be its impact on customer satisfaction, so that there will be few complaints from customers about the quality of the service. Service quality has a significant positive effect on word of mouth, the better the quality of the service provided then the more positive are the word of mouth recommendations for the service offered, so that it has an impact on the number of customer visits. Customer satisfaction has a significant positive effect on word of mouth; the greater the satisfaction felt by customers, the more frequently and positively they will recommend the business by word of mouth to others. Customer satisfaction is important to service providers, as customers spread a sense of satisfaction to potential customers, thus enhancing the company's reputation.

\section{ACKNOWLEDGMENT}

The authors thanked all parties who have helped contribute to this study.

\section{REFERENCES}

Ajami, M. P., Elola, L. N., \& Pastor, J. (2018). Validation and improvement of the European Customer Satisfaction Index for the Spanish wine sector. The TQM Journal, 30(2), 133152. https://doi.org/10.1108/TQM-07-2016-0056

Anselmsson, J., Bondesson, N. V., \& Johansson, U. (2014). Brand image and customers' willingness to pay a price premium for food brands. Journal of Product and Brand Management, 23(2), 90-102. https://doi.org/10.1108/JPBM-10-2013-0414

Bakti, I. G. M. Y., \& Sumaedi, S. (2013). An analysis of library customer loyalty:The role of service quality and customer satisfaction, a case study in Indonesia. Library Management, 34(6-7), 397-414. https://doi.org/10.1108/LM-05-2012-0025

Brown, T. J., Barry, T. E., Dacin, P. A., \& Gunst, R. F. (2005). Spreading the word: Investigating antecedents of consumers' positive word-of-mouth intentions and behaviors in a retailing context. Journal of the Academy of Marketing Science, 33(2), 123138. https://doi.org/10.1177/0092070304268417

Burnham, T. A., \& Leary, R. B. (2018). Word of Mouth Opportunity: Why Recommendation Likelihood Overestimates Positive Word of Mouth. Journal of Marketing Theory and Practice, 26(4), 368-389. 
https://doi.org/10.1080/10696679.2018.1487770

Chevalier, J., Bureau, N., \& Mayzlin, D. (2003). Working Paper Series ES \& MK Economics \& Marketing "The Effect of Word of Mouth on Sales: Online Book. National Bureau of Economic Research, 1(3), 1-34.

Fornell, C., Rust, R. T., \& Dekimpe, marnik G. (2009). The Effect of Customer Satisfaction on Cunsumer Spending Growth. Journal of Marketing Research, 36(1), 1-50.

Ghozali, I. (2014). Structural Equation Modeling Teori, Konsep dan Aplikasi dengan Program LISREL 9.10. Edisi 4. Semarang: Badan Penerbit Universitas Diponegoro.

Gopinath, S., Thomas, J. S., \& Krishnamurthi, L. (2014). Investigating the relationship between the content of online word of mouth, advertising, and brand performance. Marketing Science, 33(2), 241-258. https://doi.org/10.1287/mksc.2013.0820

Griffin, R. W. (2003). Management Jilid 1. Jakarta: Erlangga.

Gures, N., Arslan, S., \& Tun, S. Y. (2014). Customer Expectation, Satisfaction and Loyalty Relationship in Turkish Airline Industry. International Journal of Marketing Studies, 6(1), 66-74. https://doi.org/10.5539/ijms.v6n1p66

Haghighi, M., Dorosti, A., Rahmana, A., \& Hoseinpour, A. (2012). Evaluation of factors affecting customer loyalty in the restaurant industry. African Journal of Business Management, 6(14), 5039-5046. https://doi.org/10.5897/ajbm11.2765

Hair, J. F., Black, W. C., \& Babin, B. J. (2013). Multivariate Data Analysis. New Jersey: Pearson Education.

Hamenda, A. (2018). An integrated model of service quality, price fairness, ethical practice and customer perceived values for customer satisfaction of sharing economy platform. International Journal of Business and Society, 19(3), 709-724.

Handini, S., \& Ruswanti, E. (2016). Effect of Service Quality Word of Mouth With Mediation Patient Satisfaction and. Conference on Management and Behavioral Studies, 595-603.

Hisam, M. W., Sanyal, S., \& Ahmad, M. (2016). The impact of service quality on customer satisfaction: A study on selected retail stores in India. International Review of Management and Marketing, 6(4), 851-856.

Hogan, J. E., \& Lemon, K. N. (2004). Quantifying the Ripple: Word-Of-Mouth and Advertising Effectiveness Quantifying the Ripple: Word-Of-Mouth and Advertising Effectiveness. Journal of Advertising Research, 44(3), 271-280. 
Hsu, L. C. (2018). Investigating effect of service encounter, value, and satisfaction on word of mouth: An outpatient service context. International Journal of Environmental Research and Public Health, 15(1). https://doi.org/10.3390/ijerph15010132

Ilyas, A., Nasir, H., Malik, M. R., Mirza, U. E., Munir, S., \& Sajid, A. (2013). Assessing the service quality of Bank using SERVQUAL model. Interdisciplinary Journal of Contemporary Research in Business, 4(11), 390-400. Retrieved from http://journalarchieves30.webs.com/390-400.pdf

Kartawidjaja, S., Yanuar, T., \& Syah, R. (n.d.). Pengaruh Kualitas Pelayanan Terhadap Kepuasan Pasien dengan Moderasi Keterampilan Komunikasi : Studi Kasus Pada Pasien Asuransi Pemerintah Di Rumah Sakit Umum Swasta. 726-736.

Kotler, P. \& Keller, K. L. (2009). Manajemen Pemasaran. Edisi 13. Jilid 1. Jakarta: Erlangga.

Kulsum, U., \& Syah, T. Y. R. (2017). The Effect of Service Quality on Loyalty with Mediation of Patient Satisfaction. International Journal of Business and Management Invention ISSN, 6(3), 41-50. Retrieved from www.ijbmi.org

Lai, M. C., \& Chou, F. S. (2015). The Relationships among Involvement Level, Service Failure, Service Recovery Disconfirmation and Customer Lifetime Value. Journal of Economics, Business and Management, 3(4), 452-457. https://doi.org/10.7763/joebm.2015.v3.227

Lankton, N. K., \& McKnight, H. D. (2012). Examining two expectation disconfirmation theory models: Assimilation and asymmetry effects. Journal of the Association for Information Systems, 13(2), 88-115. https://doi.org/10.17705/1jais.00285

Mittal, S., \& Gera, R. (2013). Relationship between service quality di- mensions and behavioural intentions: an sem study of public sector retail banking customers in india. Journal of Services Research, 12(2), 147-171.

Mukerjee, K. (2018). The impact of brand experience, service quality and perceived value on word of mouth of retail bank customers: Investigating the mediating effect of loyalty. Journal of Financial Services Marketing, 23(1), 12-24. https://doi.org/10.1057/s41264018-0039-8

Netemeyer, R. G., Maxham, J. G., \& Lichtenstein, D. R. (2010). Store Manager Performance and Satisfaction: Effects on Store Employee Performance and Satisfaction, Store Customer Satisfaction, and Store Customer Spending Growth. Journal of Applied Psychology, 95(3), 530-545. https://doi.org/10.1037/a0017630

Ngo, V. M. (2015). Measuring Customer Satisfaction: a Literature Review. Proceedings of the 7th International Scientific Conference Finance and Performance of Firms in Science, 1(1), 
Proceedings of the 7th International Scientific Co. Retrieved from https://www.researchgate.net/publication/318827962

Nurlitasari, L., \& Syah, T. Y. R. (2016). Pengaruh Kualitas Layanan Terahadap Kepuasan Dan Loyalitas (Kasus : Rumah Sakit Medika Permata Hijau Jakarta Barat). Media Studi Ekonomi, 19 (1), 95-110.

Parasuraman, A. (1988). SERVQUAL: A Multiple-Item Scale for Measuring Consumer Perception of Service Quality (pp. 12-40). pp. 12-40. Journal of Retailing.

Rahmat Syah, T. Y. (2013). Perbedaan Pengaruh Citra Merek dan Reputasi Perusahaan Terhadap Kualitas Produk, Nilai Pelanggan dan Loyalitas Pelanggan di Pasar Bisnis. Jurnal Ekonomi Universitas Esa Unggul, 4(2).

Rampl, L. V., Eberhardt, T., Schütte, R., \& Kenning, P. (2012). Consumer trust in food retailers: Conceptual framework and empirical evidence. International Journal of Retail $\mathbb{E}$ Distribution Management, 40(4), https://doi.org/10.1108/09590551211211765

Smith, T., Coyle, J. R., \& Lightfoot, E. (2007). Reconsidering Models of Influence: The Relationship between Concsumer Social Networks and Word-of-Mouth Effectiveness. Journal of Advertising Research, 26(9), 387-397. https://doi.org/10.1016/S00319422(00)83851-0

Srinivasan, S. S., Anderson, R., \& Ponnavolu, K. (2002). Customer loyalty in e-commerce: An exploration of its antecedents and consequences. Journal of Retailing, 78(1), 41-50. https://doi.org/10.1016/S0022-4359(01)00065-3

Sugiyono. (2011). Statistik Untuk Penelitian. Bandung: Alfabeta.

Susanto. (2018). How do Service Quality and Satisfaction enhancing Customer Loyalty in Indonesia Hospital? QUALITY Access to Success, 19(167), 73-80.

Syah, T. Y. R. (2014). Fasilitas Partisipasi Provider Sebagai Pembentuk Loyalitas Pelanggan, dengan Mediasi Kualitas Relasional, dan Dimoderasi Implicit Self Theorist (Depok). Diserrtasi pada Program Dokltoral Universitas Indonesia.

Trusov, M. et al. (2000). Effect of arterio-venous fistula blood flow dynamics on ECG abnormalities in chronic hemodialysis patients. Journal of Marketing, 57(5), 258-261.

Wong, A., \& Sohal, A. (2003). Service quality and customer loyalty perspectives on two levels of retail relationships. Journal of Services Marketing, 17(5), 495-513. https://doi.org/10.1108/08876040310486285 
Yarimoglu, E. K. (2014). A Review on Dimensions of Service Quality Models. Journal of Marketing Management, 2(2), 79-93.

Yu, X., Roy, S. K., Quazi, A., Nguyen, B., \& Han, Y. (2017). Internet entrepreneurship and "the sharing of information" in an Internet-of-Things context: The role of interactivity, stickiness, e-satisfaction and word-of-mouth in online SMEs' websites. Emerald Publishing Journal, 27(1), 74-96. https://doi.org/10.1108/IntR-02-2015-0060

Zaim, H., Bayyurt, N., \& Zaim, S. (2013). Service Quality And Determinants Of Customer Satisfaction In Hospitals: Turkish Experience. International Business $\mathscr{F}$ Economics Research Journal (IBER), 9(5), 51-58. https://doi.org/10.19030/iber.v9i5.8145

Zaim, H. (2013). Service Quality And Determinants Of Customer Satisfaction In Hospitals: Turkish Experience. International Business $\mathcal{E}$ Economics Research Journal (IBER), 9, 51-58. 